\title{
TOOLS IN VIRAL TIMES: QUESTIONING THE USE OF TECHNOLOGIES IN MEXICAN SCHOOLING PRACTICES
}

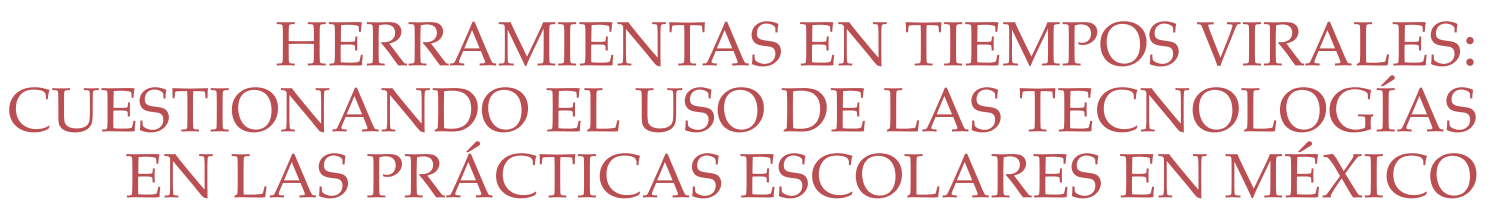

Alonso Casanueva B. ${ }^{1}$

Recibido: septiembre 18, 2020 - Aceptado: octubre 8, 2020

From 1929 to 1932, the German critical theorist Walter Benjamin broadcast a radio show intended for children, «Enlightenment for Children» (Aufklärung für Kinder). His program consisted of illuminating lessons that bound together culture and history in creative ways, to teach children about the world. Used as a tool for convivial purposes, the radio waves transported German kinder to the sites where witch trials happened, or to learn the secret language built into the city walls of Berlin, or to wonder about the life of the Romani and imagine the features of the many characters that formed part of Benjamin's radio plays. It was an imaginative pedagogical exercise that has made me wonder about the possibilities of technological tools in the service of learning experiences.

Whilst thinking about the current pandemic and the way that it has come to transform the institutions of my home country, I have come across an example that made me recall Benjamin's project. The secretariat of public education in Mexico -the institution in charge of the standardized schooling practices there- organized for the current semester to take

\footnotetext{
Commissioning editor at Thesis Eleven Journal. He has tutored courses in academic disciplines such as sociology and legal studies at La Trobe University and the Australian Catholic University, and has recently found a talent for book indexing. His doctoral research was a critical engagement with radical education through the analysis of the theories and practices of three American educationists (John Dewey, Ivan Illich, and Paulo Freire) and their interaction with the work of Cornelius Castoriadis. acasanuevaba@ltu.edu.au [Doctor en Sociología, La Trobe University, Australia, donde es docente e investigador, impartiendo también clases en The Australian Catholic University. Actualmente es editor de la publicación bimensual de teoría crítica y sociología cultural Thesis Eleven Journal https://journals.sagepub.com/home/the].
} 
place via radio, internet, but most importantly, television ${ }^{2}$. From August $24^{\text {th }}$ to the end of the school year (July 2021), thirty million Mexican students ${ }^{3}$ will enrol in school whilst relying on technologies that usually do not play a central role in their formal learning experiences. The written word has been overtaken by waves, signals, and connections.

Many aspects implied in this piece of news have made my curiosity spin. To begin, the scale of the project is enormous: this semester's studentship exceeds the total population of countries like Australia. Moreover, the diversity in ways of living and social conditions of these children means that they will adapt in more or less random and accidental ways to the transition. To top it off, the entire exercise has been put together under duress, so that it is open to uncertainties that will become challenges - to the government, teachers, parents, and students themselves.

Despite my instinctive distrust of the overarching solutions suggested by Mexican authorities (one of the natural products of a Latin American process of socialization), I have set out to understand certain aspects central to this phenomenon. My greatest reservation has to do with what will be lost during the transition. For some time now, I have been an advocate of dialogical action as an indispensable condition for creative schooling practices, and it has seemed to me that the unquestioning engagement with technologies (including the internet) as pedagogical instruments speaks against the centrality of conversation. Nonetheless, there is the Benjaminian example mentioned above, which gives me hope in the possibility of the correct use of tools. Therefore, suspending my disbelief has become paramount to untangling the social-historical relations I perceive to be at play in this case.

Unbeknownst to many, Mexico has a long-ish history with TV schooling. In 1968, the year of student protests and of the Tlatelolco massacre, the federal government kickstarted an experimental programme to improve schooling conditions in rural areas, which they called Telesecundaria or TV-high school. The core idea of the project was to supplement the curriculum available to rural students with lessons shared via television, in an effort to assist the teachers who did not possess the capacity and/or ability to instruct every high school student in a community about everything they needed to know in order to graduate. Instead, the teacher would coordinate the lesson and the students would engage in more self-directed learning practices.

The programme survived across time and has now become an integral part of the public education system. State channels were made available for teaching purposes - the same ones that will now be used to educate the mass of Mexican children. The project took off from its initial 6569 students in 1968 to 1,231,300 adolescents in the 2004-2005 school year4.

If the structure of the telesecundaria system is anything to go by, then we should expect significant upset in Mexican schooling this semester. There will be a qualitative shift in the relation that exists between teachers and students across the country, as each of these parties will see their roles modified. Teachers this semester will learn how to facilitate materials, for only a few will be lucky enough to appear on television and share their vocation with the world. This will inevitably detract attention from the usual authority displayed by the teachers, from their

2 En: https:// www.gob.mx/sep/es/articulos/boletin-no-234-inicia-manana-bajo-la-modalidad-a-distancia-el-ciclo-escolar-2020-21-sep?idiom=es

3 En: https:// www.gob.mx/sep/articulos/boletin-no-245-beneficia-regreso-a-clases-aprende-en-casa-ii-a-30-millones-de-ninas-ninos-adolescentes-y-jovenes-sep?idiom $=\mathrm{es}$

En https://www.inee.edu.mx/wp-content/uploads/2019/04/P1C306.pdf 
attempts to convey themselves as role models. Instead, their main function seems to be to distribute notebooks and exams safely to their pupils, and to communicate with them about queries regarding the information contained within these. Moreover, the Mexican teacher who is usually driven to discipline and keep order by use of the punitive gaze will see their power reduced or placed into hibernation.

On the other hand, a new set of pressures will fall upon the students. Mass schooling suffers from obliging learners to complete a set of information tasks, rather than becoming interested in them. Now they are asked to trust technologies that have been historically demonised, as they have otherwise proved to enable addiction to trash shows available at any other time of the day. According to government communiques, students will receive from their schools the notebooks that need filling out, whilst relying on the instruction of their new celebrity-teachers (the telesecundaria system is partially famous for having included in their didactics a number of videos that use actors to teach information in a more appealing fashion). Yet, this may bring about a larger wave of dropouts than under «normal» conditions. The UN expects that out of the thirty million students in the country, one point five million will disengage ${ }^{5}$. According to the Mexican political scientist Viridiana Ríos, this statistic indicates a setback of five years in the education levels ${ }^{6}$ of the entire country.

The tele-semester will present an interesting challenge in terms of content as well. Regular schooling relies on books and notebooks, where curriculum is printed out for students to read through and fill out. Even in the telesecundaria system, television is supposed to work as a supplement in the learning experience. However, there is enough room to understand that, left to one's own devices, the student will privilege the media over the written word (especially if said written word is one's own). The tables have been turned.

The present educational experiment mixes the potions of culture and schooling in uncertain quantities. Proof of this is the visual offer available to students. I have examined some lessons taught via online TV, and many are truly inventive. The listings range from inspiring animated stories spoken in náhuatl (one of the many indigenous languages of the country) to tacky soap operas that teach students about the benefits of excel spreadsheets or the harmful effects that come with the use of drugs. There are resources that belong to the video archives of public libraries as well as extracts of interviews previously broadcast on foreign networks. There are TV educators who can naturally convey complex mathematical formulas, and overworked scripts that teach definitions of terms to be memorized.

With many of the familiar features of a system being exposed to an abnormality of this kind, it makes one think that there is now a virus that has lodged itself into the Mexican public education system, with little idea of whether it wishes to dismantle its present form or if it will work as a vaccine that solidifies the belief in the regular model. Two battlefields will prove particularly relevant: that fought between public and private education, and that fought between the cities and their surrounding regions. The latter is already showing signs of disparity. Despite the fact that the infrastructure for this semester of schooling is in part made up from the telesecundaria system, it is also the case that TV-schooling in rural settings happens in a common classroom, with a single television, both currently unavailable. Then, many students will not be able to access one, two, or all of the media in question. A remote community in the state of Oaxaca ${ }^{7}$, for example, has survived for many months without

En: https://news.un.org/es/story/2020/08/1478322

En: https://politica.expansion.mx/voces/2020/08/10/violencia-que-viene

En: https://aristeguinoticias.com/2408/mexico/cuadernillos-la-herramienta-de-clases-para-estudiantes-de-santamaria-del-mar-en-oaxaca-donde-no-hay-luz-ni-internet/ 
electricity and cannot connect the children to their nationwide lessons. Fortunately, there is such a thing as the mythical «Mexican ingenuity» -the faculty to be inventive in the face of scarcity- which has allowed the local teachers to create their own materials and distribution routes to make them available to their pupils.

What the current situation brings forth is improvisation, uncertainty, and informality, all elements that theoretically can bind creativity and autonomy together. Putting naïve hopes aside, there are questions left unanswered that speak to all the dangers described: Will the students be able to taste some of the independence that comes with self-guided learning? Will the periphery speak back to the centre not only in ways that demand the installation of technological infrastructure, but also in the form of creations that impact the way we do schooling? Will schooling go back to its usual state once the promise of a vaccine becomes realized? If the times are as drastic as we feel them, so much so that they demand a transformation of the school, then there is the possibility that the answers to these questions will be equally impactful. Only in retrospect will we be able to know. Just like Benjamin's radio snuck into the lives of German children with an unexpected agenda, so will the media teach Mexican students more than what the schooling institutions can imagine (or wish for).

\section{REFERENCES}

Barroso Martínez, A.A. (2014). «La construcción social de la tecnología a propósito de la educación: el caso de la telesecundaria en México». Revista Latinoamericana de Estudios Educativos, 44(4), 107-131.

Benjamin, W. (2014) Radio Benjamin. Croydon, Australia: Verso Books.

Illich, I 1973, Deschooling Society, Ringwood, Victoria, Australia: Penguin Books.

Illich, I 1973b, Tools for Conviviality, Berkeley, Ca.: Heyday Books, Berkeley, Ca.

Una versión anterior de este texto fue publicada en Thesis Eleven como parte de la serie "Living and Thinking Crisis 2020". 